\title{
Protection Norms and Human Rights: A Rights-Based Analysis of the Responsibility to Protect and the Protection of Civilians in Armed Conflict
}

\begin{abstract}
In the international context, human rights are rarely secured by the black letter of law, but rather by the soft laws, political policies and moral prescriptions of protection norms. Two key international protection norms are the well-established Protection of Civilians in Armed Conflict (PoC) and - recently added in the last decade - the Responsibility to Protect (RtoP). Yet there is substantial confusion about the specific nature of these two norms, their relationship to one another, and their relationship to the human rights that are held to ground and shape each of them. These questions are complex not merely because there are several distinct PoC norms, nor because all these norms differ one from another. The complexity arises because the relevant differences apply to separate dimensions of each norm. In this way it is possible for a norm to be in one sense narrower than another, yet in another sense to be deeper, and in distinct further senses to be both broader and weaker. With such intricacies in mind, this paper develops a five-dimensional rights-based analysis of norms and uses it to differentiate RtoP from three separate PoC norms, and to illustrate the distinct ways each protection norm provides multi-layered rights protection.
\end{abstract}

\section{Keywords}

Responsibility to Protect; Protection of Civilians in Armed Conflict; Human Rights; Rights Theory; International Humanitarian Law; Peacekeeping; United Nations.

\section{INTRODUCTION}

As far as international norms ordinarily progress, RtoP has had a rise little short of meteoric. First formulated in 2001, accepted in the UN World Summit Outcome Document (WSOD) of 
2005, and affirmed a year later by the UN Security Council in Resolution 1674, this emerging norm has come a remarkable distance in a short time. ${ }^{1}$ The idea that states bear responsibility for protecting their civilians from atrocity crimes and that the international community bears supplementary and default responsibilities should states fail to fulfil their primary responsibility has become part of the language - if not yet the consistent policy - of international affairs. ${ }^{2}$ Given this swift journey - and given its accompanying controversies it is natural to consider RtoP's relationship to other, prior international norms that may provide support for it. In particular, the relationship between RtoP and norms governing PoC has garnered much attention. ${ }^{3}$ As compared to RtoP, PoC is a more familiar and widely-

\footnotetext{
${ }^{1}$ International Commission on Intervention and State Sovereignty (ICISS), The
} Responsibility to Protect (Ottawa: IDRC, 2001); '2005 World Summit Outcome Document', UNGA Res. 60/1, 16 September 2005, III138-140 [hereinafter WSOD]; S/RES/1674, 28 April 2006, Preamble.

${ }^{2}$ Monica Serrano, 'Implementing the Responsibility to Protect: The Power of R2P Talk', Global Responsibility to Protect, 2: 167-77 (2010).

${ }^{3}$ For previous analyses of the relationship see: Ekkehard Strauss, 'A Bird in the Hand Is Worth Two in the Bush: On the Assumed Legal Nature of the Responsibility to Protect', Global Responsibility to Protect, 1/3: 291-323 (2009), pp. 305-6; Victoria Holt and Tobias Berkman, The Impossible Mandate? Military Preparedness, the Responsibility to Protect and Modern Peace Operations (Washington: The Henry L. Stimson Center, 2006), pp. 35-56; Charles Hunt, Protection of Civilians and the Responsibility to Protect: Perspectives and Precedents in the Asia-Pacific, Program on the Protection of Civilians (Brisbane: AsiaPacific Centre for the Responsibility to Protect, 2009), p. 8; Linnea Bergholm and Cristina Badescu, 'The Responsibility to Protect and the Conflict in Darfur: The Big Let-Down', 
accepted norm. Its requirements are set down in the Geneva Conventions, and its history dates back through UN peacekeeping operations and the mandate of humanitarian organizations like the International Committee of the Red Cross (ICRC). As such, widely shared PoC duties have seemed to many as a potentially powerful way of motivating political and legal support for the more controversial aspects of RtoP, while the operationalization of RtoP will necessarily require situating it amongst dedicated PoC institutions and instruments.

The purpose of this paper is to explicate the different versions of RtoP and $\mathrm{PoC}$ as rightsbased-norms. (RtoP and PoC are here termed 'norms' in the philosophical-cum-ethical sense that they are prescriptive claims on agents decreeing what ought to be done - not in the descriptive sense wherein 'norm' connotes embedded expectations of behaviour, nor in the legal sense connoting binding legal instruments.) As a right comes to be specified and concretised into a specific norm, a variety of questions must be answered regarding the type of human concern at stake, the threats arrayed against that concern, the agents who must protect against the threats, and the types of protective responses required of them. Different answers to these questions specify different dimensions of the resultant norm. This paper develops a five-dimensional analysis for delineating the properties of a given norm, and applies this analysis to six norms gathered under the rubrics of RtoP and PoC. To anticipate the major conclusions, the analysis shows that there are deep structural similarities between the RtoP and PoC norms, reflective of their use of distinct 'waves of duties' to achieve multilayered protection of the specific rights within their scope. Both norms help fill gaps in the

Security Dialogue, 40/3: 287-307 (2009), pp. 292-93; Turid LaeGreid, Protecting Civilians from Harm: A Humanitarian Perspective, NUPI Report No. 6, 2008; GCR2P, Policy Brief: The Relationship between the Responsibility to Protect and the Protection of Civilians in Armed Conflict (Update), Global Centre for the Responsibility to Protect, 9 May 2011. 
other's coverage, and both are responsive - in different ways - to the inevitable trade-off between the breadth of a norm's ambit on the one hand, and the efficacy of that norm in terms of policy-formulation and assignation of distinct responsibilities on the other.

The next section of this paper adumbrates the key RtoP and PoC concepts. The third section develops the five-dimensional rights-based approach to analysing norms, and the following section applies this analytic device to the six protection norms previously described. The fifth section discusses some further results arising from this analysis.

\section{THE RESPONSIBILITY TO PROTECT AND THE PROTECTION OF CIVILIANS IN ARMED CONFLICT}

This section outlines the 'Three Pillars' of RtoP and distinguishes three separate PoC concepts.

\section{A. The 'Three Pillars' of the Responsibility to Protect}

The RtoP asserted in Paragraphs 138-140 of the WSOD invoked a multi-layered set of responsibilities in order to effect the protection of populations from four atrocity crimes: genocide, ethnic cleansing, war crimes and crimes against humanity. The 2009 UN SecretaryGeneral Report on RtoP used a 'Three Pillars' approach to flesh out the brief paragraphs of the WSOD. ${ }^{4}$ In summary:

RtoP Pillar One: State Protection Responsibilities: Drawing on the first three sentences of WSOD Paragraph 138, the 2009 Report delineates the domestic responsibilities of the state centrally, to refrain from committing atrocity crimes on its own citizens. In addition, Pillar One responsibilities require the state to, i) inculcate appropriate social values, ii) build

\footnotetext{
${ }^{4}$ UN Secretary-General, Implementing the Responsibility to Protect, A/63/677, 12
} January 2009. 
security, judicial, legislative and civil society institutions that facilitate protection, and, iii) consider the use of various learning devices and training capacities (including peer-review and NGO programmes). ${ }^{5}$

RtoP Pillar Two: Consensual International Protection Responsibilities: Drawing on the respective final sentences of WSOD Paragraph 138 and Paragraph 139, the 2009 Report describes the international community as having two types of Pillar Two responsibilities, viz. to persuade other states to perform their Pillar One duties, and to help them build capacities empowering them to fulfil those responsibilities. This latter can include such measures as providing a UN or regional presence, granting development assistance, aiding states' security sectors, and building mediation and dispute resolution capacities. ${ }^{6}$ Developing capacities for early warning and assessment are a further part of the international community's Pillar Two responsibilities. $^{7}$

Pillar Three: Non-Consensual International Protection Responsibilities. The Report draws on the first sentence of WSOD Paragraph 139 to delineate pacific measures that the international community can use in response to states that are manifestly failing to fulfil their Pillar One duties. These measures include fact-finding investigations, alerting states to their legal responsibilities, public advocacy, and imposing sanctions and arms embargoes. ${ }^{8}$ The Report then draws on the paragraph's second sentence to note the coercive use of force for protective
${ }^{5}$ Ibid., III 13-27.
${ }^{6}$ Ibid., TII 35-48.
${ }^{7}$ Ibid., Annex; UN Secretary-General, Early Warning, Assessment and the Responsibility to Protect, A/64/864, 14 July 2010.

${ }^{8}$ Implementing the RtoP, III 51-59. 
purposes, and the corollary responsibilities of individual states, the UN General Assembly, the Secretariat, and the Security Council in this regard. ${ }^{9}$

Together these three pillars aim to form an integrated principle ensuring the protection of all populations from the four atrocity crimes.

\section{B. Three Protection of Civilians Norms}

There are three key PoC concepts at work in international law and relations. ${ }^{10}$ These concepts map on to the different perspectives brought to PoC by three sorts of international actors: combatants, peacekeepers, and the UN Security Council.

Before proceeding, two cautionary notes. First, this list is not exhaustive. For instance, over the past decade the concept of Humanitarian PoC used by humanitarian agencies like Oxfam
${ }^{9}$ Ibid., बII 56, 60-66.
${ }^{10}$ The methodology utilised to delineate these norms involved analysing the protection concepts and practices used by those international actors who understand themselves to be - and are widely taken to be - animated or constrained by PoC: Combatants, Peacekeepers, and the UN Security Council and Secretariat (though see n. 11 below for additional PoC actors). While arguing that each of these three groups have different concepts of PoC, this paper nevertheless vindicates their grouping under the larger PoC rubric, given the shared Scope (see §IV below) of their concepts. For further literature underwriting these PoC concepts, see Hugh Breakey, 'Review and Analysis 2012: The Responsibility to Protect and the Protection of Civilians in Armed Conflict', Working Paper developed from paper presented at the Responsibility to Protect and the Protection of Civilians in Armed Conflicts Academic-Practitioner International Workshop, Sydney, Australia. Nov. 17-18, 2010 (2012). Available at: http://www.academia.edu/attachments/7555067/download_file. 
and the ICRC to protect endangered civilians has developed into a distinct PoC norm, worthy of analysis in its own right. ${ }^{11}$ It is passed over here only for the sake of parsimony. Second, distilling large bodies of law, discourse or practice into tractable normative concepts concepts that can be usefully compared one to another - inevitably involves some simplification. What follows is not the only way that PoC concepts can be delineated. ${ }^{12}$ Still,

${ }^{11}$ See, for example, Hugo Slim and Andrew Bonwick, Protection: An ALNAP Guide for Humanitarian Agencies (London: Overseas Development Institute, 2005); Inter-Agency Standing Committee IASC, Growing the Sheltering Tree: Protecting Rights through Humanitarian Action, Programmes and Practice Gathered from the Field (Geneva: UNICEF, 2002); Sorcha O'Callaghan and Sara Pantuliano, Protective Action: Incorporating Civilian Protection into Humanitarian Response, HPG Report 26, December 2007; Oxfam, Protection into Practice (Oxford: Oxfam, 2005).

${ }^{12}$ In a spirit of transparency, consider several potentially controversial areas of this analysis. In regard to Combatant PoC, International Humanitarian Law (IHL) instruments such as the Laws of Occupation and (arguably) the Genocide Convention impose duties to positively protect civilians from threats from third-parties, not merely to refrain from contributing to those threats. Such responsibilities move beyond the presented account of Combatant PoC. In regard to Peacekeeping PoC, it might be thought more perspicuous to have several distinct peacekeeping civilian protection concepts (see, for example, Holt and Berkman, The Impossible Mandate? pp. 37-44) rather than one overarching concept. In regard to Security Council PoC, this paper takes the UN Secretary-General Reports and Security Council Resolutions over the last decade as a whole, and as making up a coherent (albeit amorphous and aspirational) concept. To the contrary, it may be urged that changes in emphasis and ambit over the years suggest shifts in the core protection norm at work. 
even for readers who perceive a different notion of civilian protection at work in (say) UN Secretary-General reports, the following five-dimensional analysis should prove useful in providing the tools to clearly articulate where and how their renderings differ from the ones here presented.

Combatant PoC. The core of the first PoC concept - Combatant PoC - is constituted by the principle: 'We must not harm or unduly risk harm to the unarmed'. Combatant PoC arises from the moral code of jus in bello - the Just War constraints on the methods and modes of war - and is constituted by the legal instruments of International Humanitarian Law (IHL) particularly the Geneva Conventions of 1949 and the Additional Protocols of $1977 .{ }^{13}$ The dictates of Combatant PoC are for the greater part constraints on actions and strategies that harm or risk harm to non-combatants. They are negative duties decreeing what the moral agent should not do (as opposed to positive duties that command the moral agent perform certain actions or pursue certain goals). In technical terms such obligations are classic agentcentred deontological duties. ${ }^{14}$ Combatant $P o C$ responds to a wide range of important human

${ }^{13}$ For expository ease the recent ICRC study of customary IHL is here taken as a canonical statement of Combatant PoC. Jean-Marie Henckaerts, 'Study on Customary International Humanitarian Law: A Contribution to the Understanding and Respect for the Rule of Law in Armed Conflict', International Review of the Red Cross, 87/857: 175-212 (2005). The fundamental guarantees to civilians provided in IHL treaties are outlined in Common Article Three of the Geneva Conventions and Article Four of the Second Additional Protocol.

${ }^{14}$ Expressed in the form of rights, they are 'side-constraints' on actions: Robert Nozick, Anarchy, State, and Utopia (Oxford: Basil Blackwell, 1974), pp. 29-30. Note though that many different ethical and rights-based systems can utilize these sorts of rights without 
interests, forbidding assaults not only on a person's life, but upon their bodily security in general, their private property and cultural property, and much else besides. They restrain not only harmful actions, but actions that risk harm, such as placing civilians in harm's way, or using certain sorts of civilian objects for military purposes. ${ }^{15}$ Not all the obligations of Combatant PoC are negative duties ('thou shalt not...') however. The 'we' in 'we must not harm...' is to be read expansively as implying 'all those on our side' and even all those under our influence or supply. As such, Combatant PoC includes positive actions such as educating and training one's armed forces in their responsibilities, and in policing their behaviour. ${ }^{16}$ Additionally, Combatant PoC includes obligations for combatants to distinguish themselves from civilians, and so to contribute to an environment that minimises risks to civilians. ${ }^{17}$

Peacekeeping PoC: The second PoC norm - Peacekeeping PoC-consists of the duties a force acquires when it undertakes peacekeeping operations, including traditional peacekeeping and more robust peace-enforcement operations. The core of Peacekeeping PoC is that: 'Taking responsibility for peace enforcement in an area necessarily involves taking responsibility for the protection of civilians in that area'. Peacekeeping PoC obligations are thus role-based duties that are taken on by countries, institutions and organs when they

holding them to be ethically basic. For instance, negative rights have a key place in the political systems of utilitarians like Jeremy Bentham and John Stuart Mill, and of interesttheory-rights regimes like that of Henry Shue (see text to n. 69 below).

\footnotetext{
${ }^{15}$ Henckaerts, 'Study on Customary IHL', Rules 17, 22-24.

${ }^{16}$ Ibid., Rules 139-144, 158.

${ }^{17}$ Ibid., Rule 106.
} 
undertake peace-support operations. ${ }^{18}$ Just as one cannot assume a role of a company director, for example, without inheriting a cluster of legal duties, so too one cannot engage in peacekeeping without inheriting Peacekeeping PoC obligations. These obligations are the norms that guide, for example, UN operational discussions, reports such as the influential Brahimi Report, and other Department of Peacekeeping Operations (DPKO) and Department of Field Support (DFS) documents. ${ }^{19}$ Like Combatant PoC, Peacekeeping PoC is responsive

${ }^{18}$ For assertions of such a conditional responsibility, see Lakhdar Brahimi, Report of the Panel on UN Peace Operations, A/44/305-S/2000/809, 21 August 2000, IIII 1, 5, 49, 52, 63, 266-7 [Hereinafter Brahimi Report]; Siobhán Wills, 'Military Interventions on Behalf of Vulnerable Populations: The Legal Responsibilities of States and International Organizations Engaged in Peace Support Operations', Journal of Conflict and Security Law, 9/3: 387-418 (2004), pp. 388, 407, 417-8; Anne Ryniker, 'The ICRC's Position on 'Humanitarian Intervention", International Review of the Red Cross,/482: 527-32 (2001), p. 530; UN Secretary-General, Report to the Security Council on the Protection of Civilians in Armed Conflict, S/1999/957, 8 September 1999, III 58-61 [hereinafter UNSG 1999 Report]. See also reports in: Victoria Holt, Glyn Taylor, and Max Kelly, Protecting Civilians in the Context of UN Peacekeeping Operations: Successes, Setbacks and Remaining Challenges (New York: DPKO, UNOCHA, 2009), p. 200; Holt and Berkman, The Impossible Mandate?, pp. 4-5.

${ }^{19}$ Brahimi, Brahimi Report; Holt, Taylor, and Kelly, UN Peacekeeping Operations; but note Siobhán Wills, Protecting Civilians: The Obligations of Peacekeepers (Oxford: Oxford University Press, 2009), pp. 38-40 (2009). The DPKO - and the UN more generally only began to accept Peacekeeping PoC after Annan's appointment as Secretary-General in 1997, and the norm has been recently invigorated (since 2009) by the attention of the General Assembly’s Special Committee on Peacekeeping Operations ('C34 Committee’). See DPKO/DFS, Draft Operational Concept on the Protection of Civilians in United Nations 
to a wide range of human rights and needs that require protection, but unlike Combatant PoC, Peacekeeping PoC demands active protection against armed third-parties. ${ }^{20}$ While Peacekeeping $\mathrm{PoC}$ responds to many very different human needs, its fundamental application is the protection of civilians from mass violence - from large-scale slaughter, assault and rape. ${ }^{21}$ Peacekeeping $P o C$ does not require the impossible; complete protection over an entire Peacekeeping Operations, 2010; DPKO/DFS, Lessons Learned Note on the Protection of Civilians in United Nations Peacekeeping Operations: Dilemmas, Emerging Practices and Lessons, 2010; DPKO/DFS, Framework for Drafting Comprehensive Protection of Civilians Strategies in UN Peacekeeping Operations, 20 Jan, 2011. Peacekeeping PoC is also to be found in the work of the UN's Office for the Coordination of Humanitarian Affairs (OCHA). However, reflective of their broad role of co-ordinating disparate protection agents combatants, peacekeepers, the UN Security Council and the DPKO - OCHA deploys all of the PoC concepts discussed here, including Humanitarian PoC. See, for example, OCHA, OCHA on Message: Protection, Version 1, June 2010.

${ }^{20}$ Outside the specific case of occupation, Combatant PoC puts forward few general obligations of protection against third parties. The most promising source of such obligations is Common Article One of the Geneva Conventions providing that the Parties 'respect and ensure respect' for the Conventions. However, there are substantial problems with interpreting this article to imply general duties of protection against third parties: see Carlo Focarelli, 'Common Article 1 of the 1949 Geneva Conventions: A Soap Bubble?', European Journal of International Law, 21/1: 125-71 (2010).

${ }^{21}$ Holt, Taylor, and Kelly, UN Peacekeeping Operations, pp. 6, 21; Victoria Holt and Joshua Smith, Halting Widespread or Systematic Attacks on Civilians: Military Strategies \& Operational Concepts (Washington: Henry L. Stimson Center, 2008), p. 5. 
region is rarely achievable for any peacekeeping operation. The norm has two minimum standards, however. The first is that the peacekeeping operation must fulfil its mission mandate, including the protection of civilians objectives outlined therein. Such objectives as are issued by the UN Security Council are constrained by caveats, such as 'within capabilities and areas of deployment' and with 'respect to the responsibilities' of the host state. ${ }^{22}$ The second minimum standard prevents mandating bodies from dissolving all Peacekeeping PoC duties by simply watering down mission mandates. This standard is delineated by the natural and reasonable expectations of relevant agents - including external observers, host governments, the peace-support actors themselves and, most importantly, the local civilians whose safety is at stake - as to what counts as appropriate protection. ${ }^{23}$ It is, without question, a contentious matter as to what counts as reasonable expectations about appropriate protection, and this paper will not attempt a definitive answer. ${ }^{24}$ Suffice to say that there is some level of protection civilians can reasonably demand from local

${ }^{22}$ For example, S/RES/1270, 22 October 1999, II 14; S/RES/1509, 19 September 2003, I[3(j); S/RES/1590, 24 March 2005, II 16(i); S/RES/1933, 30 June 2010, II 16(b).

${ }^{23}$ Holt, Taylor, and Kelly, UN Peacekeeping Operations, pp. 22, 200; Holt and Smith, Halting Widespread or Systematic Attacks, p. 9; UN, Report of the Independent Inquiry into the Actions of the United Nations During the 1994 Genocide in Rwanda, UN Doc S/1999/1257/Annex, 16 December, 1999, p. 51; Wills, 'Military Interventions on Behalf of Vulnerable Populations', 388, 405, 408-9; Brahimi Report, p. 11.

${ }^{24}$ While the application of international law to UN peacekeepers is uncertain, one way forward would be to hold that the spirit of such laws as Common Article One of the Geneva Conventions of 1949 applies at least to the extent of defining the minimum moral (rather than legal) Peacekeeping PoC duties. 
peacekeepers - at the very least requiring protection from preventable mass violence in the immediate vicinity of the peacekeeping force and not abandoning civilians in the peacekeeper's care to the depredations of waiting genocidaires ${ }^{25}-$ and that failure to achieve this threshold de-legitimates the mission in the eyes of all concerned.

Security Council PoC: The third PoC norm, Security Council PoC, requires that: 'Where feasible, basic rights of bodily integrity should be protected from large-scale violation'. This is the PoC norm as it appears in UN Secretary-General Reports and Security Council Resolutions on the Protection of Civilians in Armed Conflict. ${ }^{26}$ Like Combatant PoC and Peacekeeping PoC, Security Council PoC responds to a wide variety of large-scale threats to human rights - to, 'mutilations in Sierra Leone, genocide in Rwanda, ethnic cleansing in the Balkans or disappearances in Latin America... ${ }^{, 27}$ In particular it concerns itself with especially vulnerable populations like women, children and displaced persons. ${ }^{28}$ Unlike Combatant PoC, Security Council PoC prompts positive action to protect rights against third ${ }^{25}$ Wills, Protecting Civilians, pp. 266-272. The former failure occurred in, for example, Kosovo in 2004, the latter in Rwanda 1994 and Srebrenica 1995. Ibid., pp. 220, $154,269-70$.

${ }^{26}$ The UN Secretary-General reports stretch from: UNSG, 1999 PoC Report, to UN Secretary-General, Report to the Security Council on the Protection of Civilians in Armed Conflict, S/2010/579, 11 November 2010. With regard to the Security Council: OCHA, Aide Memoire: For the Consideration of Issues Pertaining to the Protection of Civilians in Armed Conflict, 4th ed. (New York: United Nations, 2011).

${ }^{27}$ UNSG, 1999 PoC Report, I[2. Similarly, note the wide compass of concerns in OCHA, Aide Memoire, pp. 9-32.

${ }^{28}$ For example OCHA, Aide Memoire, pp. 12-14, 25-32. 
parties. And unlike Peacekeeping PoC, Security Council PoC is not contingent upon deploying troops or undertaking peace operations. Rather, Security Council PoC constitutes the reason for deploying troops, preventing conflict, and taking other actions to protect civilians from mass rights-violations. Such actions can be quite diverse, including prevention, peace-making, peacekeeping, peace-building, and intervention. As well as calling for parties to observe IHL (that is, to observe Combatant $P o C$ ) and condemning them when they do not, the responses called for by Security Council PoC can include the use of targeted sanctions, asset freezes, arms embargoes and travel bans, ${ }^{29}$ setting up ad hoc courts (as in the former Yugoslavia ${ }^{30}$ and $\mathrm{Rwanda}^{31}$ ), and referring situations to the International Criminal Court (as in Darfur ${ }^{32}$ and recently Libya ${ }^{33}$ ). At the limit the Council can authorise the use of military force to protect civilians: while Security Council 1973 concerning Libya is in substance an instance of RtoP, ${ }^{34}$ the text itself authorises military force under the explicit rubric of PoC. ${ }^{35}$

${ }^{29}$ Ibid., pp. 18, 57-69.

${ }^{30}$ S/RES/827, 25 May 1993.

${ }^{31}$ S/RES/955, 8 November 1994.

${ }^{32}$ S/RES/1593, 31 March 2005.

${ }^{33}$ S/RES/1970, February 26 2011, IIII. 4-5. RtoP is mentioned only regarding the Libyan government's responsibility to protect its people, not with respect to the reasons behind the Council's action.

${ }^{34}$ And was affirmed as such in: UN Secretary-General, 'Statement by the SecretaryGeneral on Libya', 17 March 2011, http://www.un.org/apps/sg/sgstats.asp?nid=5145, accessed 17th March 2011. Note, though, that in S/RES/1973, RtoP is mentioned only regarding the Libyan government's responsibility to protect its people, and not with respect to the reasons animating the Council's action. 
Security Council PoC is thus a wide and diffuse notion, appearing as a significant but unspecified inducement to respond, through prevention, response and capacity-building, to widespread, human-inflicted suffering.

These three PoC norms are of course not mutually exclusive. For instance, the UN Security Council may decide, prompted by Security Council PoC, to undertake a protective mission that will, in the usual case, be bound by positive Peacekeeping PoC duties as well as the perennial action-constraints of Combatant PoC.

The following sections use a rights-based approach to differentiate and analyse these three PoC norms and the three RtoP pillars. This decision to characterise these norms as rightsbased is itself open to question. This is especially so in cases (outside Combatant PoC and RtoP Pillar One) where there are few determinate legal duties and the obligations are 'soft' rather than hard law. Some theorists have held that this lack of hard duties in RtoP must imply an absence of correlative rights. ${ }^{36}$ This issue will be addressed more fully in Section V, which will argue that the use of multi-layered, backup and open-ended duties - characteristic of both PoC and RtoP - is emblematic of rights-based norms. For now it is worth noting two points. First, human rights, reflective of their general stature in international law and their central place in the UN Charter, are perennially invoked as undergirding and structuring both

${ }^{35}$ S/RES/1973, 17 March 2011, III[4-5. Res. 1973 was thus both an RtoP and a PoC Resolution: See Hugh Breakey and Angus Francis, 'Points of Convergence and Divergence: Normative, Institutional and Operational Relationships between R2P and PoC', Security Challenges, 7/4: 41-52 (2011).

${ }^{36}$ David Rodin, 'The Responsibility to Protect and the Logic of Rights', in Oliver Jütersonke and Keith Krause (eds.), From Rights to Responsibilities (Geneva: Programme for Strategic and International Security Studies (PSIS), 2006). 
PoC and RtoP. ${ }^{37}$ Second, the necessity for rights to require direct correlating duties in hard law has been widely critiqued over the last several decades, to the point where no major theory of rights now holds this view. ${ }^{38}$ As such, it is mistaken to conclude that the absence of determinate legal duties in (for example) RtoP Pillar Three or Peacekeeping PoC indicates the absence of a grounding in rights.

\section{A FIVE-LEVEL RIGHTS-BASED APPROACH TO ANALYSING NORMS}

Rights, norms, obligations and responsibilities can differ from one another on a variety of separate dimensions. The literature on protection norms reflects the fact that one norm can be at once deeper, narrower and stronger than another. ${ }^{39}$ However, without due attention to the specific nature of each dimension, and a clear and systematic apparatus for referring to each, it is easy for subtle but crucial differences between norms to be effaced. The following

${ }^{37}$ With respect to RtoP: ICISS, The Responsibility to Protect, pp. 1-8, 13-14; the WSOD places RtoP under its human rights rubric (rather than security): WSOD, III138-139. With respect to PoC, human rights are central in the widely endorsed ICRC definition of protection: S. G. Caverzasio, Strengthening Protection in War: A Search for Professional Standards (Geneva: International Committee of the Red Cross, 2001), p. 19; OCHA, OCHA on Message: Protection, p. 1; IASC, Growing the Sheltering Tree.

${ }^{38}$ See the arguments and references in Hugh Breakey, 'User's Rights and the Public Domain', Intellectual Property Quarterly,/3: 312-23 (2010), pp. 317-18.

${ }^{39}$ Secretary-General, Implementing the Responsibility to Protect, p. 8; Gareth Evans, 'The Responsibility to Protect: An Idea Whose Time Has Come... And Gone?', International Relations, 22/3: 283-98 (2008), p. 294; Hitoshi Nasu, 'Operationalizing the 'Responsibility to Protect' and Conflict Prevention: Dilemmas of Civilian Protection in Armed Conflict', Journal of Conflict \& Security Law, 14/2: 209-41 (2009), pp. 213-18. 
taxonomy aims to provide such an apparatus, and thus may also prove useful to scholars, practitioners and human rights actors working in fields outside civilian protection, who similarly need to delineate and distinguish rights-based norms at work in their domain. ${ }^{40}$

The five dimensions (this paper will refer to them as levels) of a rights-based norm are as follows:

Level One: The Concern. This first level describes the feature of the individual human that normatively warrants protection. ${ }^{41}$ This may be an interest, action, choice or capability of an individual. ${ }^{42}$ For example, a person's interest in their ongoing life and health, their ability to

${ }^{40} \mathrm{~A}$ further, more technical, intention is to provide an analytical device that is neutral as regards different theories of rights. While the final section of this paper draws particularly on the work of Jeremy Waldron and Henry Shue, the apparatus described in this section can be used to map rights as conceived by all major theories of rights, including interest, capacity, legal positivist, choice, and side-constraints theories, though each such theory will disagree regarding at which level, strictly speaking, the right has emerged.

${ }^{41}$ Level One may also describe the subset of persons protected by the norm, if it is less than universal. The six norms dealt with in this paper are universal, but the norms and institutional mandates of Humanitarian PoC, for example, make substantial and sophisticated use of specification at this level. See O'Callaghan and Pantuliano, Protective Action, p. 13.

${ }^{42}$ See, respectively, Joseph Raz, The Morality of Freedom (Oxford: Clarendon Press, 1986), pp. 165-192; Isaiah Berlin, 'Two Concepts of Liberty', Four Essays on Liberty (London: Oxford University Press, 1969), pp. 121-27; H. Hart, 'Are There Any Natural Rights?', Philosophical Review, 64: 175-91 (1955); Amartya Sen, 'Elements of a Theory of Human Rights', Philosophy and Public Affairs, 32/4: 315-56 (2004). 
move freely, their choice of religion, and their capability to engage in productive work have all been advanced, at various times, as concerns of individual humans that warrant protection in their own right.

Level Two: Scope. This second level describes what types of infractions or threats against the (Level One) object of concern the norm is intended to protect against. For instance, a norm might protect a person's life from the threat of violent death but not from the threat of preventable disease. Alternatively, the norm might only protect against large-scale threats, or threats from one particular agent (such as the state) and not another (an ordinary individual). Once the Level Two Scope has been delineated we have what is sometimes termed a 'Prima Facie' or 'Manifesto' right - a right as it appears in constitutions, Bills of Rights, and popular discourse. It may not yet be clear exactly whose role it is to fulfil the right, or exactly what such fulfilment will require - but the concern the norm is envisioned to protect, and the paradigm threats that it will protect against, have been settled.

Level Three: Responsibility. The third level decrees whose role it will be - or how it will be affixed whose role it will be - to protect the individual's concern from the earmarked threats. Such a responsibility may be general and universal, such as the ubiquitous responsibility not to murder. Or it may be conditional, awaiting the attaining of a specific status or capacity (such as paying progressive taxes when one has a high income) or of a relationship (such as a parent holding duties regarding their child). Level Three Responsibility thus describes who has the responsibility for protecting against the threat, and when and under what conditions they acquire that responsibility.

Level Four: Response. This fourth level describes the type of actions that are required by, or prohibited for, the responsibility-holder in order to protect against the threats. These types of responses can be classified in many different ways. A familiar distinction, already touched 
upon, contrasts duties that require only forbearance from some specific action (negative duties, for example, of non-interference) with duties that require specific actions to be performed (positive duties, for example, of rescue). More sophisticated distinctions may be drawn at this key level. For example, moral philosophers, international lawyers and human rights practitioners have each found it helpful to further subtilise positive duties into obligations to, (i) directly protect against threats from third-parties, (ii) indirectly protect against threats by contributing to the building of preventive social institutions, and (iii) aid those who have previously been harmed by the threats. ${ }^{43}$

Level Five: Strength/Precise Duties. This final level delineates precisely who must do what, and what happens if they do not. It is here that arise all the fine-grained Hohfeldian relations prized by the legal theorist - the privileges, claims, duties, powers, immunities, liabilities and so on that detail exactly what the norm involves for each party. ${ }^{44}$ As well as concretizing and specifying the four prior notions of concern, threat, responsibility and type-of-response into precise duties and entitlements, Level Five may also be termed the Strength of the norm, for it

${ }^{43}$ For example, Henry Shue, Basic Rights: Subsistence, Affluence and US Foreign Policy (Princeton: Princeton University Press, 1980), pp. 52-62; Jeremy Waldron, Liberal Rights (New York: Cambridge University Press, 1993), p. 24; Committee on Economic Social and Cultural Rights CESCR, Outline for Drafting General Comments on Specific Rights of the International Economic, Social and Cultural Rights, E/2000/22, E/C.12/1999/11, Annex IX 19th November 1999; Emma McClean, 'The Responsibility to Protect: The Role of International Human Rights Law', Journal of Conflict and Security Law, 13/1: 123-52 (2008), pp. 144-6; IASC, Growing the Sheltering Tree, p. 115.

${ }^{44}$ W. Hohfeld, Fundamental Legal Conceptions, as Applied in Judicial Reasoning, ed. W. Cook (New Haven: Yale University, 1946). 
describes with what force the norm presses its requirements into the lives of its duty-holders, and what other constraints, duties and rights it can trump as it does so. Level Five further specifies whether the imposed duties are legal obligations - and, if so, whether the failure to perform them invites sanction, criminal or otherwise. If, on the other hand, the duties are nonlegal moral obligations, ${ }^{45}$ then Level Five dictates whether they are obligations that have little latitude in how, when and toward whom they must be performed (perfect duties), wide latitude in how when and toward whom they must be performed (imperfect duties) ${ }^{46}$ or are aspirations rather than necessities (supererogatory duties). Even more subtle distinctions may be drawn at Level Five. This is particularly true in an international context, where a norm notwithstanding that it is widely accepted to be a genuine legal obligation - can have no courts or tribunals to adjudicate on it. ${ }^{47}$

\section{ANALYSIS OF THE SIX PROTECTION NORMS}

Rather than exhaustively list the properties of all six protection norms under all five levels (a task that would try the reader's enthusiasm for detail), this section will move through each level in turn and describe the noteworthy features that arise.

\section{Level One: Concern}

${ }^{45}$ The Hohfeldian apparatus can be applied to all normative entitlements, thus allowing it to delineate the precise moral, as well as legal, relations arising at Level Five. See Leif Wenar, 'The Nature of Rights', Philosophy and Public Affairs, 33/3: 223-52 (2005).

${ }^{46}$ See Violetta Igneski, 'Perfect and Imperfect Duties to Aid', Social Theory and Practice, 32/3: 439-66 (2006); Patricia Greenspan, 'Making Room for Options: Moral Reasons, Imperfect Duties, and Choice', Social Philosophy and Policy, 27/2: 181-205 (2010).

${ }^{47}$ Kenneth Abbott and Duncan Snidal, 'Hard and Soft Law in International Governance', International Organisation, 54/3: 421-56 (2000). 
PoC's concerns are broader than RtoP's. RtoP, in all its Pillars, is concerned only with the human interests in life and the most basic bodily security. These concerns lie at the base of the four atrocity crimes of genocide, ethnic cleansing, war crimes and crimes against humanity. While these interests in life and bodily security are also signature concerns for PoC, all three PoC norms extend further. Combatant PoC includes, for example, concern for human interests in ongoing sustenance and medical treatment, in freedom of movement, and in holding cultural and private property. ${ }^{48}$ Likewise Peacekeeping PoC and Security Council PoC respond to a similarly broad gamut of interests. ${ }^{49}$

\section{Level Two: Scope}

The three RtoP norms are narrow not only in terms of the type of human interests they protect (at Level One), but also in terms of the types of threats against those interests that fall under their scope (at Level Two). RtoP focuses exclusively on large-scale and widespread threats of violence in the form of the four atrocity crimes: genocide, crimes against humanity, war crimes and ethnic cleansing. ${ }^{50}$ The three PoC norms respond not only to the threats to life and

\footnotetext{
${ }^{48}$ Henckaerts, 'Study on Customary IHL': Regarding freedom of movement and
} displacement: Rules 129-33; Sustenance and medical attention: Rules 25-32, 53-56, 110, 118 ; Cultural and private property: Rules, 38-41, 49-52; Discrimination: Rule 88.

${ }^{49}$ See $n .51$ below, and accompanying text.

${ }^{50}$ WSOD, $\uparrow 138$; Scheffer describes how atrocity crimes must meet a 'substantiality test', limiting RtoP to 'megacrimes that assault civilian populations wholesale': David Scheffer, 'Atrocity Crimes: Framing the Responsibility to Protect', in R. H. Cooper and J. V. Kohler (eds.), Responsibility to Protect: The Global Moral Compact for the 21 st Century (New York: Palgrave MacMillan, 2009), pp. 82-83. 
limb characterised by atrocity crimes, but also to the threats posed by the targeting of civilians in combat, sexual assault and exploitation, forced displacement, application of starvation strategies, the deliberate blocking of urgent humanitarian aid, and more. ${ }^{51}$ Combatant PoC has the widest scope of all, as the other five norms are concerned with specifically large-scale threats. Combatant $\mathrm{PoC}$, however, also prohibits isolated and discrete actions, performed by small groups and even individuals acting alone.

Many comparisons of PoC and RtoP insist upon a key difference in their scope; RtoP can apply to threats occurring outside armed conflict, while PoC norms cannot. ${ }^{52}$ After all, it can seem a logical truth that norms regarding 'The Protection of Civilians in Armed Conflict' must apply only in situations of armed conflict. On this footing, RtoP is wider in scope in the sense that it can apply to non-standard cases of conflict, such as the situations of mass civil violence that created genocide in Rwanda and Darfur. But upon examination this point of difference is difficult to sustain. For one thing, the legal threshold for armed conflict triggering Combatant PoC (application of the Geneva Conventions and Additional Protocols) is not demanding, requiring only the presence of armed resistance with a military structure or

${ }^{51}$ Henckaerts, 'Study on Customary IHL' pp. 198-212; Brahimi Report, IIII37-43; Holt, Taylor, and Kelly, UN Peacekeeping Operations, pp. 19, 170, 192, 205; Holt and Berkman, The Impossible Mandate? pp. 21, 39-44; OCHA, Aide Memoire.

${ }^{52}$ For example, Strauss, 'A Bird in the Hand'; Jennifer Welsh and Maria Banda, 'International Law and the Responsibility to Protect: Clarifying or Expanding States' Responsibilities?', Global Responsibility to Protect, 2: 213-31 (2010), p. 216; GCR2P, Policy Brief, p. 3. 
of UN troops being involved in fighting. ${ }^{53}$ These conditions would have been fulfilled in most recent atrocity cases - including Rwanda, Srebrenica, Kosovo, Darfur, the Democratic Republic of the Congo, and Libya. For another, there is no constraint regarding 'armed conflict' evinced either in Peacekeeping PoC or Security Council PoC; while peacekeepers and the Council do focus on large-scale and sudden assaults on civilians, they do not evidence any concern whatsoever for whether those assaults are occurring inside or outside an 'armed conflict' narrowly construed. ${ }^{54}$ This wide scope of PoC explains why RtoP was affirmed by the Security Council under the larger rubric of its thematic interest in $\mathrm{PoC}^{55}-$ the scope of Security Council PoC includes but is not limited to the scope of RtoP.

\section{Level Three: Responsibility}

Profound differences between the norms emerge at Level Three. Combatant PoC and RtoP Pillar One impose universal duties, and apply to all persons and states. Peacekeeping PoC, on the other hand, is conditional and role-based. It applies only to institutions, nations, regional organisations and/or UN organs if they undertake peacekeeping operations in a region, or make assurances to do so.

${ }^{53}$ Robert Kolb and Richard Hyde, An Introduction to the International Law of Armed Conflicts (Oxford: Hart Publishing, 2008), pp. 78-81.

${ }^{54}$ For example the Brahimi Report (p. 11) speaks simply of 'violence against civilians' as a sufficient reason for UN peacekeepers to respond. Similarly the SecretaryGeneral explicitly invokes cases entirely removed from armed conflict: UNSG, 1999 PoC Report, I[2. Member States in UNSC Open Debates on PoC regularly assert its ambit as stretching beyond the confines of armed conflict: see, most recently, S/PV.6650, 9 November 2011, pp. 15-17, 25.

${ }^{55}$ S/RES/1674, 28 April 2006. 
For the remaining three protection norms, the allocation of responsibility to specific actors is less clear. These norms all apply to the 'international community' as a whole, and it is a contested issue exactly how that responsibility is to be distributed amongst different agents. It is clear enough, however, that the United Nations is a key player. It will fall to various organs of the United Nations to institutionalise and allocate RtoP Pillar Two duties like the development of effective early-warning mechanisms and the provision of protection expertise and support for willing but struggling states. With regard to Security Council PoC, the Council takes upon itself, pursuant to the UN Charter, the capacity to make decisions regarding condemnations, sanctions, embargoes, referrals to international tribunals and so on. As for the controversial third pillar of RtoP, the Council is alone entrusted with the role of authorising the use of coercive measures. Arguably, it thus inherits the accompanying moral (not legal) responsibility to judiciously perform that role. Outside the United Nations, the allocation of duties by these three protection norms is even less straightforward. Regional organisations may in specific cases be vested with duties analogous to (though less formal than) the above-noted responsibilities placed on the UN organs. Duties of particular nations are less clear again - especially when it comes to deploying valuable military and police assets into non-permissive environments. In the limit case regarding the military elements of RtoP Pillar Three, the WSOD does not stipulate how to assign what is, euphemism aside, a duty to wage war for protective purposes, and this question is not even settled in theory, much less in policy or law. ${ }^{56}$

\footnotetext{
${ }^{56}$ See James Pattison, 'Whose Responsibility to Protect? The Duties of Humanitarian Intervention', Journal of Military Ethics, 7/4: 262-83 (2008); Kok-Chor Tan, 'The Duty to Protect', in T. Nardin and M. Williams (eds.), Nomos XLVII: Humanitarian Intervention (New York: New York University, 2006).
} 


\section{Level Four: Response}

The core obligations of Combatant PoC and of RtoP Pillar One are negative duties not to harm civilians. However, each norm includes some positive duties aimed at preventing harms. As well as requiring the training and policing of one's own forces to conform to its rules, Combatant PoC mandates distinct ways - such as by distinguishing themselves as combatants and not using human shields - that individual combatants can contribute to a larger environment where civilian security is enhanced. Likewise RtoP Pillar One requires some positive efforts at structural prevention, including inculcating appropriate values in the citizenry and building institutions that facilitate protection. Positive structural prevention duties move to centre stage in RtoP Pillar Two, which involves a wide array of strategies, including monitoring and early-warning activities, capacity-building, aiding in disputeresolution and more.

A wide and open-ended arsenal of responses, reflective of the agents' proximity to endangered civilians, is found in Peacekeeping PoC. These include capacity-building and peace-building, facilitating humanitarian aid, conflict resolution and aiding political processes, and - in some cases at least - the direct physical protection of civilians against violence. These diverse Peacekeeping PoC obligations are, however, constrained by caveats in terms of the feasibility, legality and capacity of the peacekeepers to perform these actions. $^{57}$

Finally, the large strategic toolkit of RtoP Pillar Three and Security Council PoC includes condemnation, preventive diplomacy, establishing international criminal tribunals, enacting sanctions, arms embargoes, the separation of civilians and combatants, ensuring humanitarian

\footnotetext{
${ }^{57}$ See above n. 22.
} 
aid, establishing safe zones, the protection of refugees, monitoring, reporting, counteracting hate media and (ultimately) authorizing military intervention for protective purposes. ${ }^{58}$ Many of these strategies must be weighed against respect for sovereignty and the international norm of non-intervention, which is why the Security Council plays a pivotal decision-making and authorisation role in both these norms.

\section{Level Five: Strength/Precise Duties}

Combatant PoC and RtoP Pillar One are for the most part determinate legal requirements. To violate either of these norms is - in the overwhelming majority of cases - to break IHL, International Human Rights Law, the Laws of Occupation, and/or the Genocide Convention. At the other extreme lie the duties imposed on the international community generally by Security Council PoC, and RtoP Pillars Two and Three. The widespread (though not entirely uncontested $^{59}$ ) view of these prescriptions is that they are not legal duties, but only moral or political ones. ${ }^{60}$ Setting aside duties to use one's powers to pressure parties under one's

${ }^{58}$ Secretary-General, Implementing the Responsibility to Protect, IIII: 51-66; OCHA, Aide Memoire. The UNSC authorized military force in Libya with S/RES/1973, 17 March 2011. Note also the 2011 action by French forces in Côte D'ivoire: Alex Bellamy and Paul Williams, 'The New Politics of Protection? Côte D'ivoire, Libya and the Responsibility to Protect', International Affairs, 87/4: 825-50 (2011), pp. 829-838; S/RES/1975, 30 March 2011.

${ }^{59}$ Louise Arbour, 'The Responsibility to Protect as a Duty of Care in International Law and Practice', Review of International Studies, 34/3: 445-58 (2008).

${ }^{60}$ With respect to the status of the second and third pillars of RtoP as 'soft law', see Welsh and Banda, 'Clarifying or Expanding States' Responsibilities?', p. 230; Carsten Stahn, 'Responsibility to Protect: Political Rhetoric or Emerging Legal Norm?', American Journal of 
influence and support from committing genocide in other states (which is a legal duty, as the ICJ has determined ${ }^{61}$ ), the international community acts wrongly if it reneges on its positive RtoP duties, but it breaks no law in doing so. Indeed, because these duties refer to the pursuit of goals, leaving wide latitude in how and when they are to be pursued, they are best characterised as imperfect moral duties. This wide latitude can, in certain contexts, make it difficult for third parties to tell whether the duty has been breached in any given instance. These requirements are thus soft norms, not hard laws. ${ }^{62}$ Indeed, Security Council PoC is explicitly softened; the Council's use of terms like 'willingness', 'preparedness', and 'standing ready', suggests it sees action on its part as not obligatory at all. If so, then Security Council PoC is not an imperfect duty, but rather a supererogatory one. Still, it may be that some limited RtoP Pillar Three duties are undergoing a slow process of solidification. So much might be implied by the outcry over the Russian-Chinese veto of the proposed UNSC Resolution on Syria on February $42012 .{ }^{63}$

The status of Peacekeeping PoC at Level Five is controversial. While some of its duties are goal-directed and so have the latitude of imperfect duties, at least some of its demands are determinate. Earlier it was posited that a peacekeeping operation that fails to protect civilians International Law, 101/1: 99-120 (2007), pp. 118-120; Arbour, 'Duty of Care'; Stephanie Carvin, 'A Responsibility to Reality: A Reply to Louise Arbour', British International Studies Association, 36: 47-54 (2010).

${ }^{61}$ See the summary in Arbour, 'Duty of Care', pp. 451-55.

${ }^{62}$ Abbott and Snidal, 'Hard and Soft Law in International Governance'.

${ }^{63}$ Consider the outrage of a medic in Syria shortly after the resolution was blocked: 'This is the Russian and Chinese veto! These are pieces of people.' (quoted in James Hider and Laura Pitel, 'Bloodied Homs Residents Slam UN Vetoes,' The Times, 7 February 2012). 
in its most immediate environment and before its very eyes, or abandons those in their care to the depredations of waiting genocidaires, fails in its Peacekeeping $P o C$ duties. Even in such cases however, where there is a striking failure of moral duty, it is doubtful there is a breach in law. ${ }^{64}$ Still, this issue is uncertain, having to do with the idiosyncratic legal status of UN troops, the minutiae of the Status of Forces Agreements (SOFAs) between the United Nations and the host state, the Memorandum of Understanding (MOU) between the United Nations and the troop-contributing country, the troop-contributing country's treaty commitments, and the extent to which international humanitarian law, international human rights law, the Genocide Convention and (especially) the Law of Occupation are applicable to peacekeeping operations. $^{65}$

\section{DISCUSSION AND RESULTS}

Several noteworthy results arise from the foregoing analysis.

\section{A. The relationship between Ambit and Efficacy}

The five-dimensional analysis allows a clear expression of Ban Ki-Moon's point that RtoP is 'narrow and deep. ${ }^{66}$ RtoP is narrow in terms of its Level One Concern and Level Two Scope. Compared to all the PoC norms, RtoP's ambit is tightly constrained, responding only to the

\footnotetext{
${ }^{64}$ Wills describes how legal acknowledgment of positive peacekeeping protection
} obligations is much more controversial than recognition of the negative constraints of IHL (Combatant PoC): Wills, Protecting Civilians, pp. 187-88.

${ }^{65}$ Ibid.; Bruce Oswald, Helen Durham, and Adrian Bates, Documents on the Law of UN Peace Operations (New York: Oxford University Press, 2010), esp. pp. 11-13.

${ }^{66}$ Secretary-General, Implementing the Responsibility to Protect, $\mathbb{I} 10(\mathrm{c})$. See also: Evans, 'An Idea Whose Time Has Come', p. 294. 
four atrocity crimes. (Other norms, such as 'human security' and 'humanitarian intervention' could also be mapped onto the five-dimensional analytic apparatus. RtoP's scope is also narrower than both these norms.) But RtoP is deep in the sense that many different Level Four Responses are required, by many diverse actors, states and institutions, under each of its three pillars. RtoP may thus be contrasted with a norm like Combatant PoC which is 'broad but shallow.' Combatant PoC responds to a vast array of threats to human rights, but greatly restricts the mandated Level Four Responses by limiting such responses to negative duties or highly specific and situational positive duties.

In all, it is worth noting the trade-off between ambit and efficacy at work. Norms that are broad in ambit (wide in scope and deep in response) are aspirational in what they seek to cover, but that very feature makes policy-formulation on their basis difficult, and determinate responsibilities hard to assign. Proponents of both RtoP and PoC recognise this problem. ${ }^{67}$ The narrower the scope and shallower the responses prescribed by a norm, the more it can direct policy and assign concrete responsibilities and even legal accountability. However, with narrowness and shallowness comes the worry that key elements of human wellbeing, and profitable ways of protecting such wellbeing, are being left out of the equation. Balance between the two seems a sensible approach, and this position is arguably found in norms like RtoP that are narrow but deep, and like Combatant PoC that are broad but shallow.

Peacekeeping PoC presents an interesting case in this regard. Its scope is wide, and the varieties of response that might be called upon are vast. Its main mechanism of constraint

${ }^{67}$ With respect to RtoP, see: Ibid., pp. 294-5; Secretary-General, Implementing the Responsibility to Protect, I10(c); Alex Bellamy, 'The Responsibility to Protect - Five Years On', Ethics and International Affairs, 24/2: 143-69 (2010), pp. 159-60. As regards PoC, see: Holt and Berkman, The Impossible Mandate? p. 36. 
arises at Level Three Responsibility. Agents only acquire these broad and deep Peacekeeping PoC duties when they begin protection or peace support operations in a province, and then only to an extent limited by their capacities and mandate. Turning to the final PoC concept, like Peacekeeping PoC, Security Council PoC is wide in scope and deep in response. It is only rendered workable through its weakness in Level Five Strength - it imposes almost no legal duties, and, arguably, few determinate moral ones.

\section{B. PoC and RtoP as Rights-Based Norms}

The similarity between different norms crosses their terminological classifications in terms of the larger rubrics of PoC and RtoP. For example, RtoP Pillar One closely parallels Combatant PoC. Both consist for the greater part of universal, perfect, negative, legal duties. These two norms can seem to have more in common with each other than with the other norms in their larger rubric (that is, RtoP Pillar One is more akin to the Combatant PoC than it is to RtoP Pillars Two or Three). In like manner, RtoP Pillar Three is often in step with Security Council PoC, with both consisting of positive, open-ended, soft norms imposed on the international community generally.

Given these cross-cutting parallels, it may be queried whether it makes sense to divide the protection norms into the two terminological groupings of RtoP and PoC. In some ways this larger categorisation does invite error. Many discussions of PoC tend to suggest that what is true of one PoC concept is true of them all - that because one PoC norm is 'uncontroversial' or evinces 'neutrality', say, that this follows for PoC in general. But this is not so. The PoC norms are profoundly different one from another. An avid proponent of Peacekeeping PoC may hold strongly to the international principle of non-interference, and so reject the invasive and coercive aspects of Security Council PoC. A similar story is true for the intra-group differences of the RtoP Pillars. To describe RtoP as a whole as an 'emerging norm' risks at 
once overselling the status of its last two pillars, while underselling the standing in law of its first pillar. ${ }^{68}$

Despite all this, the two groupings do make sense. First, the fundamental distinction between the two groups of protection norms is made on the basis of their differences at the most basic levels of Concern and Scope. The narrowness in the scope and concerns of RtoP, as opposed to PoC, is the keystone point of difference that shapes RtoP's nature at later levels.

Second, the intra-group differences between each of the protection norms allow that group, as a whole, to provide multi-faceted protection of the specific interests that are its concern. Such multi-pronged protection is a hallmark of rights-based norms. That is, what matters for rights is the actual ground-level protection of the interest, action or choice - and many different moral agents are obliged to try a host of different strategies to effect such protection.

To explain. Henry Shue argues that basic rights should be protected by duties not to harm, duties to directly protect people from being harmed by others, and duties to contribute to institutions ensuring that duties not to harm are able to be filled by ordinary (non-saintly) humans. ${ }^{69}$ Each of these types of (Level Four) responses is required by a rights-respecting agent, because - the world being what it is - application of only one response would not amount to a decent level of protection from harm for rights-holders. Shue's multi-pronged protection is apparent in the PoC group. Clearly, the greater part of Combatant $\mathrm{PoC}$ is constituted by Shue's first type of duties - obligations to avoid harming. More subtly however, Combatant PoC also mandates distinct ways that individual combatants can contribute to environments where the necessity for enemy combatants to target civilians in

\footnotetext{
${ }^{68}$ Stahn, 'Political Rhetoric or Emerging Legal Norm?' p. 110.

${ }^{69}$ Shue, Basic Rights, pp. 52-60.
} 
order to achieve their military goals is reduced. This is Shue's third type of duty. By distinguishing themselves as combatants, not using human shields, and by ensuring their military objects are not placed amongst civilian objects, soldiers of side X create an environment where soldiers of side Y can - in principle at least - accomplish their military objectives without harming X's civilians. The core of Peacekeeping PoC, in contradistinction, is Shue's second type of duty. It is a responsibility, in this case conjoined to a particular role, to directly protect civilians from the predations of third parties. Finally, reflecting its aspirational status, Security Council PoC has elements of each of Shue's types of obligations. Pursuant to Shue's type (i) duties, the Security Council may call for conformity to IHL duties not to harm and create international courts to police such duties. Pursuant to Shue's type (ii) the Council can authorise the deployment of troops to directly protect civilians from third parties. Pursuant to type (iii), the Council is concerned with indirect structural prevention in the form of institutions, development, democracy, and capacity-building as they impact upon civilian protection. In all, the different areas of speciality at work - the normative division of labour, as it were - allows each PoC norm to act as one strut supporting a larger rights-protecting scaffold.

Like PoC, RtoP also displays this type of multi-pronged rights protection. In particular, it does so through its use of backup and open-ended duties. Paralleling Shue, Jeremy Waldron has argued that sometimes there is no determinate answer to the question: What specific actions does it take to protect a right? For when one duty fails to be performed, or fails to effect the desired protection, it is not as if moral agents must simply accept that that is the end of the matter. Instead, further duties may be called in to afford backup, or supplementary, protection. For this reason, the correct correlate of a right is not a duty, argues Waldron, but 
rather 'successive waves of duties' ${ }^{70}$ The utilisation of such waves of duties is thus a signature indicium of a rights-respecting norm. RtoP does just this - and it does so in two ways.

First, RtoP is all about backup duties. Suppose in State X group Y intends to exact a mass atrocity on Group Z. In so doing, Y will be defaulting on its duty not to harm Z. At this point, RtoP Pillar One mandates the first wave of backup duties, requiring the State act to prevent Y from performing this mass violation of Z's rights. But perhaps the State is unable? Then RtoP Pillar Two brings online a second wave of backup duties on other states and the international community to aid the State in performance of its duty. But perhaps the State is unwilling? Then RtoP Pillar Three provides a third wave of backup duties on the international community to take over the role of protector.

Second, the specific duties imposed by RtoP are open-ended. The purpose is not to have any set list of actions performed; it is to effect genuine protection by locating an agent who can properly be held responsible for such protection. ${ }^{71}$ Recasting Waldron, we might say that the proper correlate of a right is not a duty but a responsibility (or, indeed, successive waves of responsibility). RtoP, as a paradigm of a rights-based norm, fastens in on Level Three Responsibility, and locates a set of agents whose role is to protect the right, while leaving open many aspects of Level Four Response regarding how that protection will be secured. Both its plasticity and its waves of backup duties emphasise that RtoP is indeed what its

${ }^{70}$ Waldron, Liberal Rights, pp. 25, 212-19. Shue makes the point in terms of default and backup duties: Henry Shue, 'Limiting Sovereignty', in Jennifer Welsh (ed.) Humanitarian Intervention and International Relations (Oxford: Oxford University Press, 2004), pp. 16-18.

${ }^{71}$ See Edward Luck, 'The Responsibility to Protect: Growing Pains or Early Promise?', Ethics and International Affairs, 24/4: 349-65 (2010), pp. 361-62. 
progenitors claimed - a victim-centred norm. ${ }^{72}$ RtoP's central weakness, from a rights-based perspective, is not the open-endedness of its duties, ${ }^{73}$ but rather its ambiguity in who exactly holds those obligations and how they are assigned in any given case. It is here, if groundlevel rights protection is to be provided, where theoretical, legal, and institutional development of RtoP is most required.

\section{The conceptual and normative links between RtoP and PoC}

The analysis clarifies the conceptual links between RtoP and PoC. First, the substance of Combatant PoC largely overlaps RtoP Pillar One's negative duties. Given the close relationship between armed conflict and atrocity crimes,${ }^{74}$ the norm that states must not themselves commit atrocity crimes on their own populations (the negative duties of RtoP Pillar One) will usually fall inside Combatant $P o C$ 's requirement that no agent may commit serious harms to the unarmed (much less perpetrate atrocity crimes on them). Second, Peacekeeping PoC helps comprise RtoP Pillar Two, in the sense that once RtoP requires that a peace-support operation be deployed, that deployment will then be constrained by Peacekeeping PoC duties. Peacekeeping PoC and the duties of RtoP will align in mandating that peacekeeping operations ensure a basic level of protection of civilians against

\footnotetext{
${ }^{72}$ ICISS, The Responsibility to Protect, pp. 16-17.

${ }^{73}$ Indeed, it is arguable that responsibilities are stricter than mere duties, as their
} open-ended-ness obliges one to try one's best to ensure success: Joel Feinberg, 'Duties, Rights and Claims', American Philosophical Quarterly, 3/2: 137-44 (1966), p. 141.

${ }^{74}$ Alex Bellamy, Mass Atrocities and Armed Conflict: Links, Distinctions, and Implications for the Responsibility to Protect, Policy Analysis Brief (Muscatine: The Stanley Foundation, 2011), pp. 2-3. 
widespread acts of violence. ${ }^{75}$ Finally, RtoP as a whole can be seen as a specification and concretization of the amorphous and aspirational Security Council PoC. RtoP, as it were, takes one thread out of the vast tapestry of Security Council PoC and seeks to specify, legitimise, and operationalise it.

While there are thus important overlaps between PoC and RtoP, the two groups of norms also complement each other by filling gaps in the other's coverage. As observed, Security Council $P o C$ is massively ambitious in terms of its Level Two Scope, and wide-ranging as regards its potential Level Four Responses. It expresses the shared normative concern with all the myriad mass violations of human rights that 'cry out' for 'something' to be done. However, the precise duties at Level Five imposed by Security Council PoC are minimal. It is true that, once decisions are made at an executive level, the more determinate role-based Peacekeeping $P o C$ duties emerge. However, there remains a fundamental disconnect between Security Council PoC and Peacekeeping PoC because authorised bodies like the UN Security Council have no determinate responsibilities to act. This is one reason why RtoP may prove significant in the slow march of human rights protection against atrocity crimes. RtoP Pillars Two and Three offer the possibility of functioning as bridging norms. Because RtoP narrowly limits its attention in Level Two Scope, it is able to put forward determinate responsibilities at Level Three and even approach the instantiation of precise duties at Level Five. Indeed, the norm's very name - the Responsibility to Protect - connotes its deliberate focus upon this pivotal Level Three. Through filling out in some detail Level Three Responsibilities, RtoP forms a bridge over the normative chasm that lies between the amorphous aspirations of Security Council PoC and the determinate role-based duties of Peacekeeping PoC.

\section{CONCLUSION}

\footnotetext{
${ }^{75}$ Wills, Protecting Civilians, pp. 251-57.
} 
This paper has developed a five-dimensional rights-based analysis of norms and used it to tease apart different features of the three pillars of RtoP, and of three distinct PoC norms. Upon analysis, while clear overlap can be seen between RtoP and PoC, important differences emerge. PoC accomplishes the protection of civilians' rights through three separate norms that together cover prohibitions on harm, direct protection against harms from third-parties, and institution-building to indirectly prevent future harms. RtoP affords similarly multipronged protection, but does so through the depth and open-endedness of its multiple waves of duties. While there are clear overlaps, RtoP's central focus on allocating responsibility in atrocity situations promises to fulfil a gap in the rights-based normative coverage supplied by the three PoC norms. 